Sains Malaysiana 49(8)(2020): 1809-1817

http://dx.doi.org/10.17576/jsm-2020-4908-05

\title{
Tracing the Carbon Flow in Tropical Watershed using Stable Isotope Technique
}

(Mengesan Aliran Karbon di dalam Legeh Sungai Tropika Menggunakan Teknik Isotop Stabil)

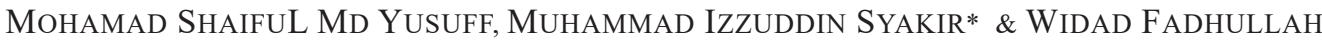

\begin{abstract}
Research on catchment area have traditionally involved concentration and flux measurement to better understand weathering, transport and cycling of materials from land to sea. Potentially, modification of terrestrial environment can alter the carbon flow in a catchment. This research is to characterize dissolved inorganic carbon (DIC) in Sungai Kurau and Tasik Bukit Merah. A progressive depletion of $\left(\delta^{13} C-D I C:-14.20 \pm 0.47 \%\right.$ ) towards downstream $\left(\delta^{13} C-D I C:-24.44 \pm 0.59 \%\right)$ is observed. The trend indicates photosynthesis activity at the upper stream system where microbial respiration process is observed to occur at the Tasik Bukit Merah located at downstream area. The dynamic of carbon pathway is highly affected by allochthonous input and autochthonous process in the catchment system. Land use activities within the catchment can disturb the balance between biological and geological processes which control the carbon pool in Kurau catchment.
\end{abstract}

Keywords: Carbon-13; carbon cycle; photosynthesis; respiration; Tasik Bukit Merah

\section{ABSTRAK}

Penyelidikan di kawasan tadahan secara tradisinya melibatkan kepekatan dan pengukuran fluks untuk lebih memahami luluhawa, pengangkutan dan kitaran bahan dari darat ke laut. Berpotensi, pengubahsuaian persekitaran daratan dapat mengubah aliran karbon dalam kawasan tadahan. Kajian ini adalah untuk mengenal pasti karbon bukan organik yang dilarutkan (DIC) di Sungai Kurau dan Tasik Bukit Merah. Pengurangan progresif ( $\delta^{13} C-D I C:-14.20 \pm 0.47 \%$ ) ke arah hiliran $\left(\delta^{13} C\right.$-DIC: $-24.44 \pm 0.59 \%$ ) diperhatikan. Petunjuk ini menunjukkan aktiviti fotosintesis pada sistem hulu sungai dengan proses respirasi mikrob diperhatikan berlaku di Tasik Bukit Merah yang terletak di kawasan hilir sungai. Dinamik laluan karbon amat dipengaruhi oleh input dan proses autoktonus dalam sistem kawasan tadahan. Aktiviti penggunaan tanah dalam kawasan tadahan boleh mengganggu keseimbangan antara proses biologi dan geologi yang mengawal kelompok karbon di kawasan tadahan Kurau.

Kata kunci: Fotosintesis; karbon-13; kitaran karbon; respirasi; Tasik Bukit Merah

\section{INTRODUCTION}

Inland waters have been termed as regulator of climate change emphasizing the role they play in global biogeochemical cycle (Williamson et al. 2009). Inland waters can modulate the overall carbon (C) balance of entire landscape, not only acting both as source of $\mathrm{C}$ to the atmosphere through evasion of greenhouse gases, such as carbon dioxide $\left(\mathrm{CO}_{2}\right)$ and methane $\left(\mathrm{CH}_{4}\right)$ but also as sinks through $\mathrm{C}$ burial in sediment of lake and reservoir. In global contexts, carbon cycle has traditionally been presented as a number of reservoirs link by transfer pathways. Namely the atmosphere, terrestrial biomass, soil, the ocean and its associated biota and the lithosphere have been identified as primary carbon repositories (Mackenzie \& Lerman 2006). The dynamic of the carbon cycle is primarily controlled by the watershed input and interim process as a result, the addition of the $\mathrm{C}$ or removed from the carbon pool (Lee 2014). The nature of the carbon cycle in tropical watersheds especially Malaysia remains poorly clarified. Few studies have addressed the contribution of Tropical River to the global carbon cycle and the resulting effects on worldwide climate. This is a subject of importance, given that tropical river provides more than $50 \%$ of the global water discharge, and therefore the largest percentage of the total fluvial carbon flux to the oceans (Meybeck 1993).

\section{DISSOLVED INORGANIC CARBON (DIC) IN FRESH WATER}

Fluvial export of dissolved carbon from the terrestrial system has been identified as an important component of the terrestrial carbon cycle (Hope et al. 1994). This 'aquatic conduit' of carbon is relatively small compared to the direct uptake and release of carbon from forested or peat dominated terrestrial systems. Dissolved $\mathrm{CO}_{2}$ 
(aqueous) in river usually derived from (1) decomposition/ mineralization of terrestrial organic matter and terrestrial root respiration (allochthonous) via soil/ groundwater, (2) $\mathrm{CO}_{2}$ emission from in-situ degradation process and (3) $\mathrm{CO}_{2}$ released during the precipitation of carbonates (autochthonous) (Zou 2016). When $\mathrm{pH}$ level decrease from the neutral level, formation of carbonic acid will occur with addition of free dissolved $\mathrm{CO}_{2}$ (Kalff 2002). Any dissolved $\mathrm{CO}_{2}$ whether is sourced from respiration of microbial activity or atmosphere, it will react to water to yield carbonic acid. Since carbonic acid is weak and it will dissociate, yielding $\mathrm{HCO}_{3}$. In low-pH lake $(<5.7)$, a high proportion of DIC is present as free $\mathrm{CO}_{2}$. In system with input from weathering factor such as dissolution of carbonate, the DIC will be dominated by $\mathrm{HCO}_{3}$ at higher pH. $\mathrm{CO}_{2}$ start dominate at $\mathrm{pH}$ above 9 .

\section{STABLE ISOTOPE AS TOOL IN FINGERPRINT DETECTION}

The isotopic composition of a carbon species can be used as an indicator of its origin and of subsequent processes leading to its modifications (Clark \& Fritz 1997). This makes stable isotope analysis a valuable tool in environments where carbon is derived from various sources. All carbon within river is ultimately sourced from atmospheric $\mathrm{CO}_{2}$, organic carbon, or carbonate mineral (Hope 1994; Meybeck 1993) each with a characteristic range of $\delta^{13} \mathrm{C}$ values (Figure 1).

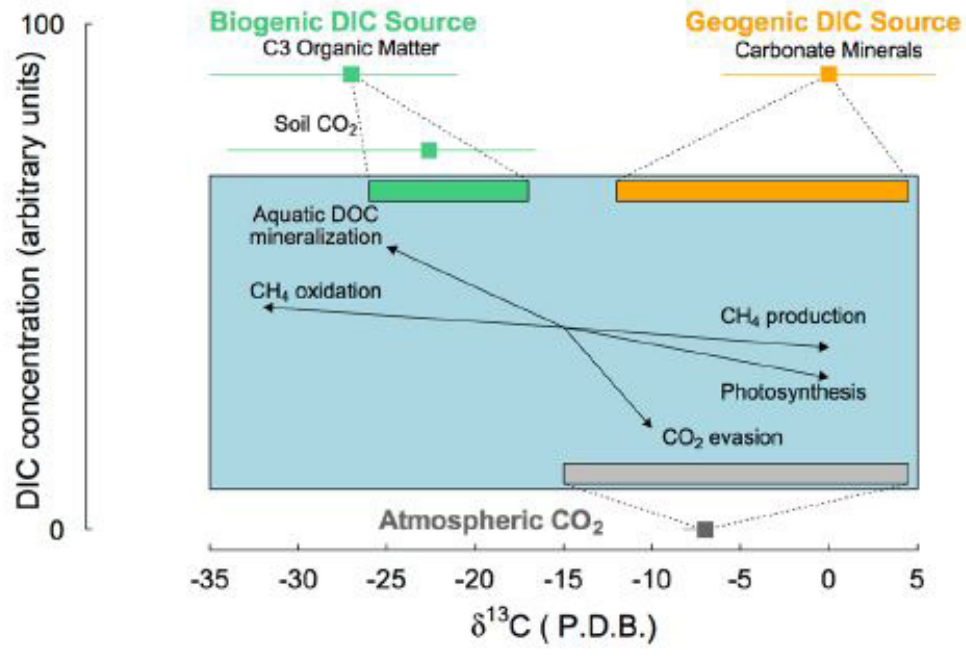

FIGURE $1 . \delta^{13} \mathrm{C}$ values of carbon from various sources. Adapted from Dubois et al. (2010)

The carbon isotope composition of a compound can also under different modification (pathway process) subsequent to production. For example, soil $\mathrm{CO}_{2}$ normally has an isotope composition which identical with the organic materials (Cerling et al. 1991). Biological processes can similarly influence the $\delta^{13} \mathrm{C}$ values of various carbon species. Organism utilizing carbon such as photosynthesis process show a preference for ${ }^{12} \mathrm{C}$, due to its more rapid reaction rate owing to kinetic and thermodynamic considerations (Park \& Epstein 1961). By product of biological activity also tend to be more $\delta^{13} \mathrm{C}$ depleted relative to the parent material. This is observed with plant uptake of $\mathrm{CO}_{2}$, in which plant tissues can be $\delta^{13} \mathrm{C}$-depleted by more than $20 \%$, as well as with bacterial uptake of carbon substrates (Farquhar et al. 1989). In case of methane production, the latter process can fractionate carbon as $-90 \%$ relative to precursor materials $\left({ }^{12} \mathrm{C}\right)$ thus, enriching the $\delta^{13} \mathrm{C}$ value (Whiticar et al. 1986).

\section{MATERIALS AND METHODS}

Field work was carried out within the Malaysian Peninsular, in watershed located in the northern region of Perak state. The area of investigation is in the Batu Kurau district, which is located $20 \mathrm{~km}$ from Taiping at the northern region of Perak. Its landscape was built up millions of years of limestone formation and pristine river. The catchment size of Kurau is $151 \mathrm{~km}^{2}$ and the Bukit Merah lake is $40 \mathrm{~km}^{2}$ (Figure 2). It is one of the oldest reservoir in the country. The reservoir was built in 1902 with the capacity of 70 million $\mathrm{m}^{3}$. The Bukit Merah Reservoir (BMR) was meant to serve the 24,000 
ha Kerian Irrigation Scheme mainly for rice cultivation. Approximately 10,000 farmers rely on rice cultivation industry. As well, the was very instrumental as fresh water resource to $\sim 300,000$ populations of Kerian and Larut
Matang Districts since 1906. In addition, it also serves as the only unique native Malaysian Golden Arowana fish sanctuary in Malaysia.

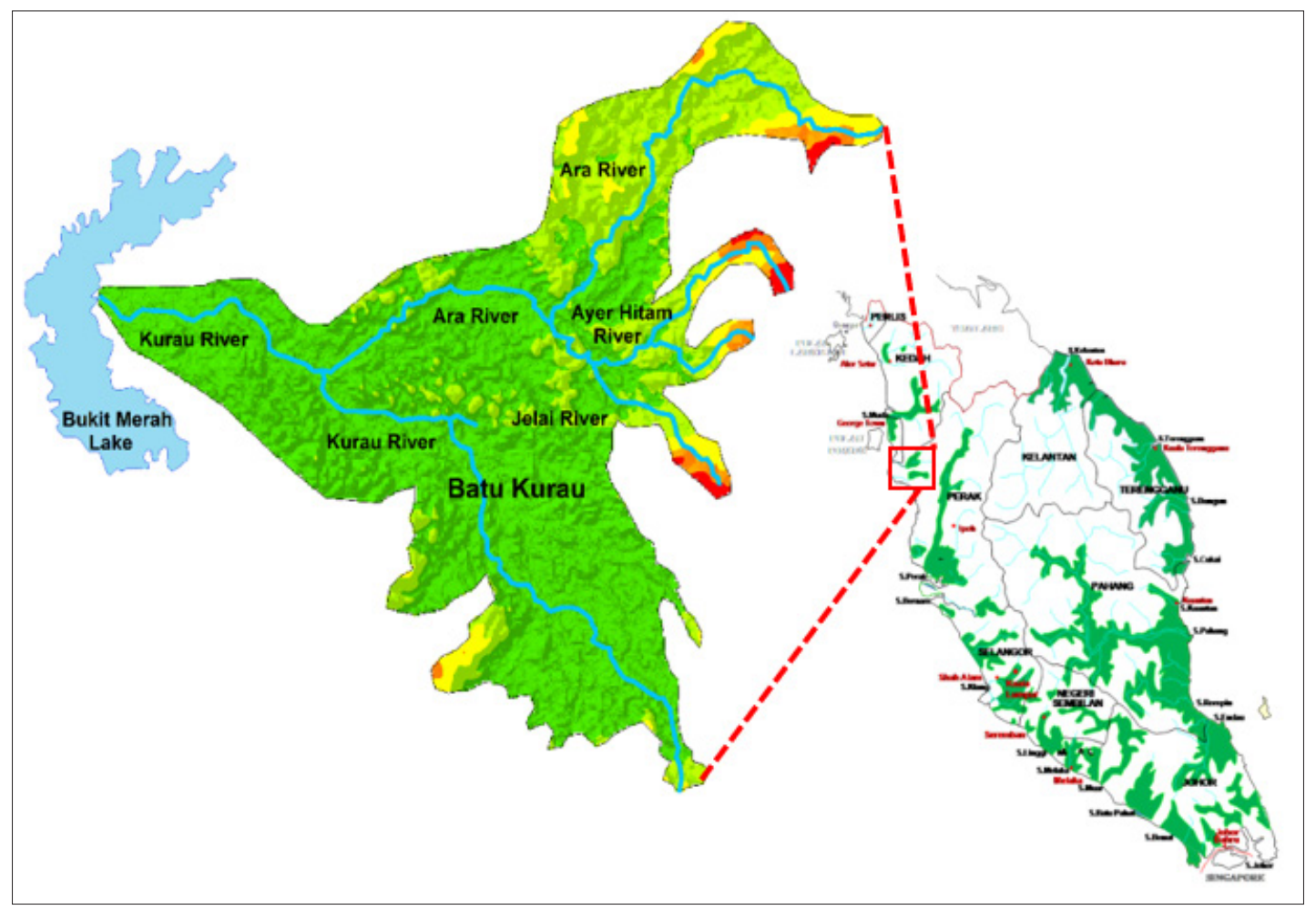

FIGURE 2. Map of Kurau Catchment

SAMPLING AND COLLECTION

Sampling took place on May 2017. The sample was collected in 2 sub environments of Kurau catchment (BMR and Batu Kurau). Ten liter of water sample for $\delta^{13} \mathrm{C}$-DIC were collected and $\mathrm{pH}$ were measured from each 11 points in the catchment (Figure 3). Precipitation of barium carbonate $\left(\mathrm{BaCO}_{3}\right)$ technique was conducted in the field or in-situ (Varlam et al. 2006).

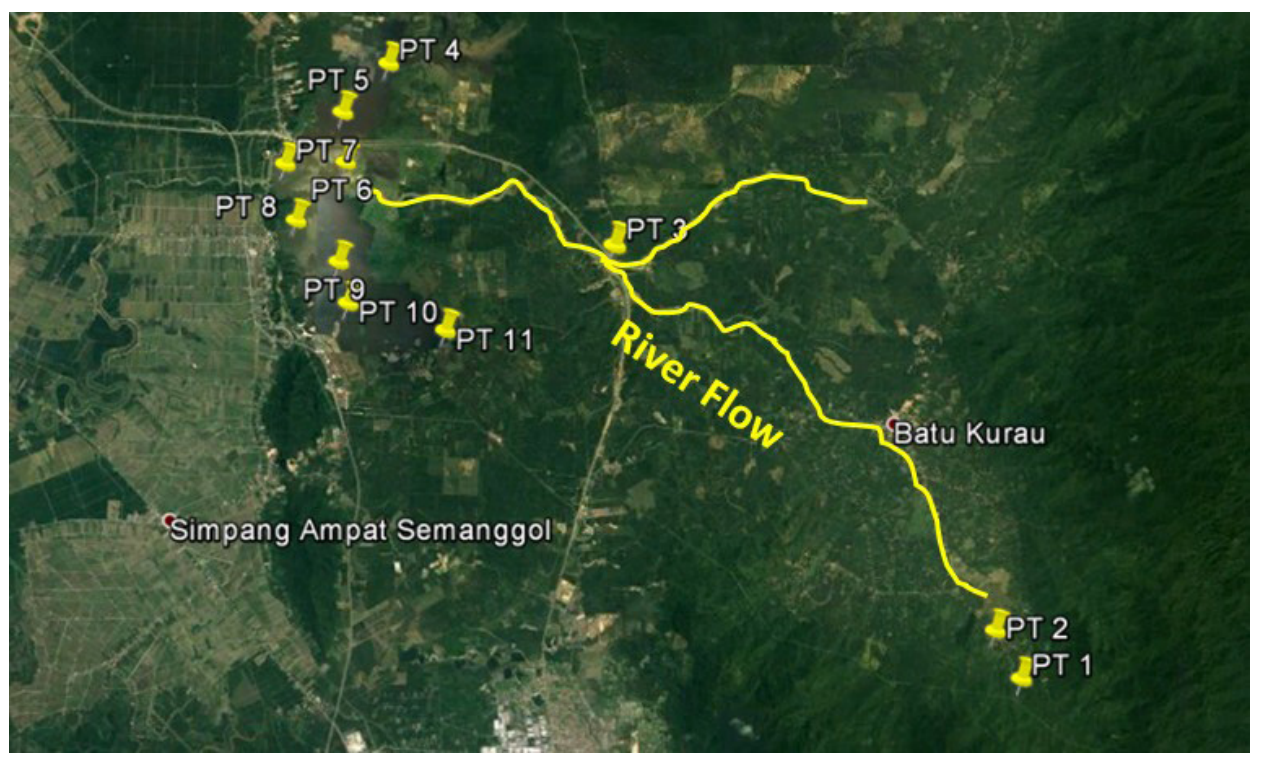

FIGURE 3. Map of sampling location. Adapted from Google Earth (2017) 
The primary technique used in this research project is the stable isotope technique. Stable isotope values are measured in units of per mil (\%o), relative to the Vienna Pee Dee Belemnite (V-PDB) standard (IAEA 1993) based on the following equation:

$$
\delta^{13} \mathrm{C} \% 0=\left(\frac{\mathrm{R}_{\text {sample }}-\mathrm{R}_{\text {std }}}{\mathrm{R}_{\text {std }}}\right) \times 10^{3}
$$

where $\mathrm{R}_{\text {sample }}$ is the ${ }^{13} \mathrm{C} /{ }^{12} \mathrm{C}$ ratio in the sample of interest, and $\mathrm{R}_{\text {std }}$ : is the ${ }^{13} \mathrm{C} /{ }^{12} \mathrm{C}$ ratio in the V-PDB standard.

The Isotope Ratio Mass Spectrometer (IRMS) are used for isotopic analysis. It is a specialised mass spectrometer which produces precise and accurate measurements of variations in the natural isotopic abundance of light stable isotopes. The samples $\left(\mathrm{BaCO}_{3}\right)$ were fed into the SERCON Water Equilibration System
(WES) before analyses using IRMS (SERCON, 2007). The samples were flushed with Helium $(\mathrm{He})$ gas with the custom setup group and 30 drops $( \pm 300 \mu \mathrm{L})$ are injected into each vial. The sample is left for $60 \mathrm{~min}$ for a reaction. Depending upon the material the time of a reaction may have to be extended (Figure 4).

Sample-acid reaction:

$$
2 \mathrm{H}_{3} \mathrm{PO}_{4}+3 \mathrm{CaCO}_{3} \rightarrow \mathrm{Ca}_{3}\left(\mathrm{PO}_{4}\right)_{2}+3 \mathrm{H}_{2} \mathrm{O}+3 \mathrm{CO}_{2}
$$

The extracted $\mathrm{CO}_{2}$ gas was sampled by a specially designed sampling needle where the flow of He carrier gas pushed the gas mixture through the needle hole into the ionization chamber of the IRMS. The standard use in $\delta^{13}$-DIC analyses is NBS $18\left(\delta^{13} \mathrm{C}=-5.014\right), \mathrm{R} 022\left(\delta^{13} \mathrm{C}=\right.$ -28.63) and IAEA-603 $\left(\delta^{13} \mathrm{C}=+2.46\right)$.

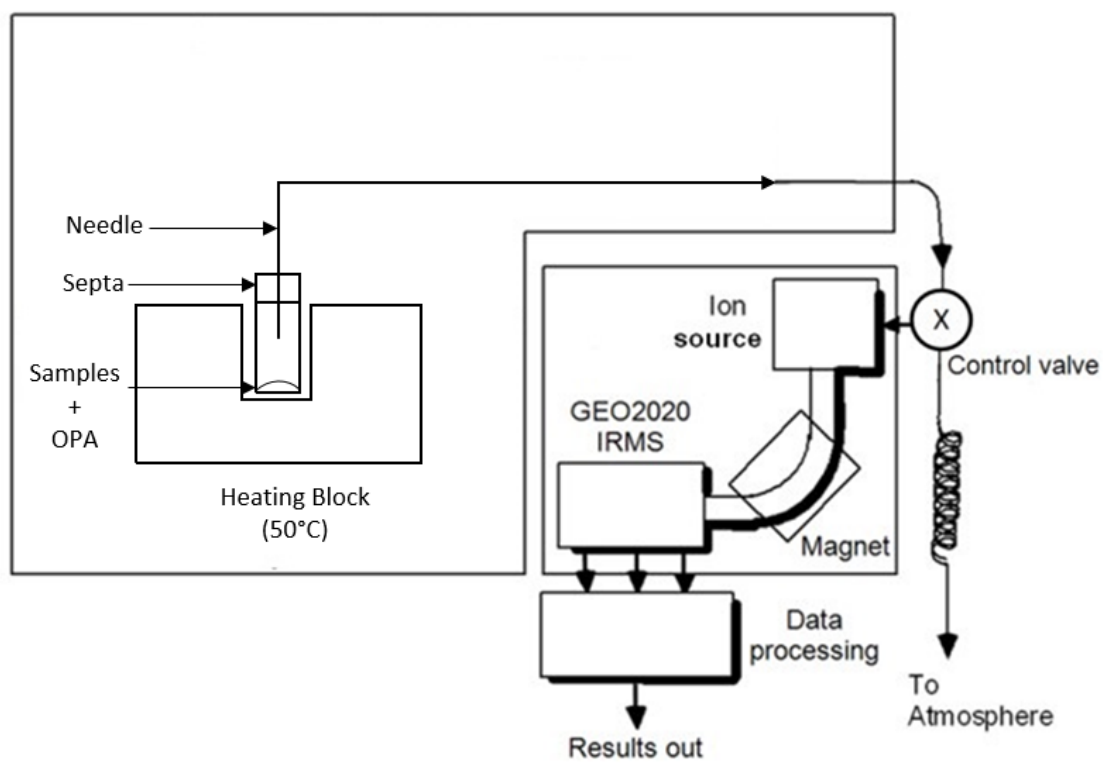

FIGURE 4. Schematic diagram of a water equilibration system (WES) in series with an IRMS for the analysis DIC

\section{RESULTS AND DISCUSSION}

Given that $\delta^{13} \mathrm{C}$-DIC values of river and lake water of Kurau catchment range is $14.20 \pm 0.47$ until $-24.44 \pm$ $0.59 \%$. The $\mathrm{pH}$ values range from $4.93 \pm 0.16$ to 8.52 \pm 0.11 . The isotopic composition of DIC and $\mathrm{pH}$ in all sampling point are presented in Table 1. All data analyse using analysis of variance (ANOVA) on single factor and regression. Sample for $\delta^{13} \mathrm{C}$-DIC mean is -19.53 with standard error of 0.90 . The confidence level is set to $95 \%$ and overall standard deviation is 2.98 . Each sample result differs with the values of $\pm 2.00 \%$. Sample for $\mathrm{pH}$ measurement mean is 7.00 with standard error of 0.35 . The confidence level is set to $95 \%$ and overall standard deviation is 1.14. Each sample result differs with the values of \pm 0.77 . 
TABLE 1. Isotopic properties of DIC in Kurau catchment

\begin{tabular}{lccc}
\hline Points & Location & $\delta^{13} \mathrm{C}-\mathrm{DIC}(\%)$ & $\mathrm{pH}$ \\
\hline PT 1 & Upstream & $-16.82 \pm 0.35$ & $7.72 \pm 0.60$ \\
PT 2 & Bat Cave & $-22.80 \pm 0.23$ & $7.52 \pm 0.51$ \\
PT 3 & Confluent & $-19.93 \pm 0.90$ & $6.70 \pm 0.09$ \\
PT 4 & Sg Merah & $-22.39 \pm 0.74$ & $5.72 \pm 0.18$ \\
PT 5 & Railway & $-24.44 \pm 0.59$ & $4.93 \pm 0.16$ \\
PT 6 & Sg Kurau & $-19.78 \pm 0.44$ & $7.35 \pm 0.05$ \\
PT 7 & Dam Gate JPS & $-19.92 \pm 0.26$ & $7.99 \pm 0.30$ \\
PT 8 & Selinsing Dam Gate & $-16.53 \pm 0.54$ & $8.22 \pm 0.28$ \\
PT 9 & Middle Lake & $-18.58 \pm 0.29$ & $8.52 \pm 0.11$ \\
PT 10 & Bkt Merah Resort & $-14.20 \pm 0.47$ & $6.34 \pm 0.44$ \\
PT 11 & Kmpg Selamat & $-19.44 \pm 0.86$ & $6.03 \pm 0.27$ \\
\hline P $\leq 0.05$ & & & \\
R $=0.50$ & & &
\end{tabular}

BIOLOGICAL AND GEOLOGICAL SOURCE OF DIC

In photosynthesis, $\mathrm{CO}_{2}$ and $\mathrm{H}_{2} \mathrm{O}$ are converted to organic matter by green plants, which use the solar light energy (photons) for this process (Berner \& Berner 2012; Ishak 2014). This occurs during ${ }^{12} \mathrm{CO}_{2}$ diffusion into the leaf stomata and dissolution in the cell sap and during carboxylation (carbon fixation) by the leaf's chloroplast where ${ }^{12} \mathrm{CO}_{2}$ is converted to carbohydrate $\left(\mathrm{CH}_{2} \mathrm{O}\right)($ Clark \& Fritz 1997). Due to selection of different isotopologue of
${ }^{12} \mathrm{CO}_{2}$ (lighter) compared to ${ }^{13} \mathrm{CO}_{2}$ (heavier), this process causes the residual of ${ }^{13} \mathrm{CO}_{2}$ is enriched in the atmosphere (Wanninkhof 1985). The heavier ${ }^{13} \mathrm{CO}_{2}$ invaded into the stream and remain in the water due to differential partial pressure of $\mathrm{CO}_{2}$ and under-saturated conditions in the water column (Karim et al. 2011). As a result, high concentration of ${ }^{13} \mathrm{CO}_{2}$ accumulated in the water causing the $\delta^{13}$-DIC to be enriched. This happen because $\mathrm{CO}_{2}$ have high solubility at low temperature (Weiss 1974).

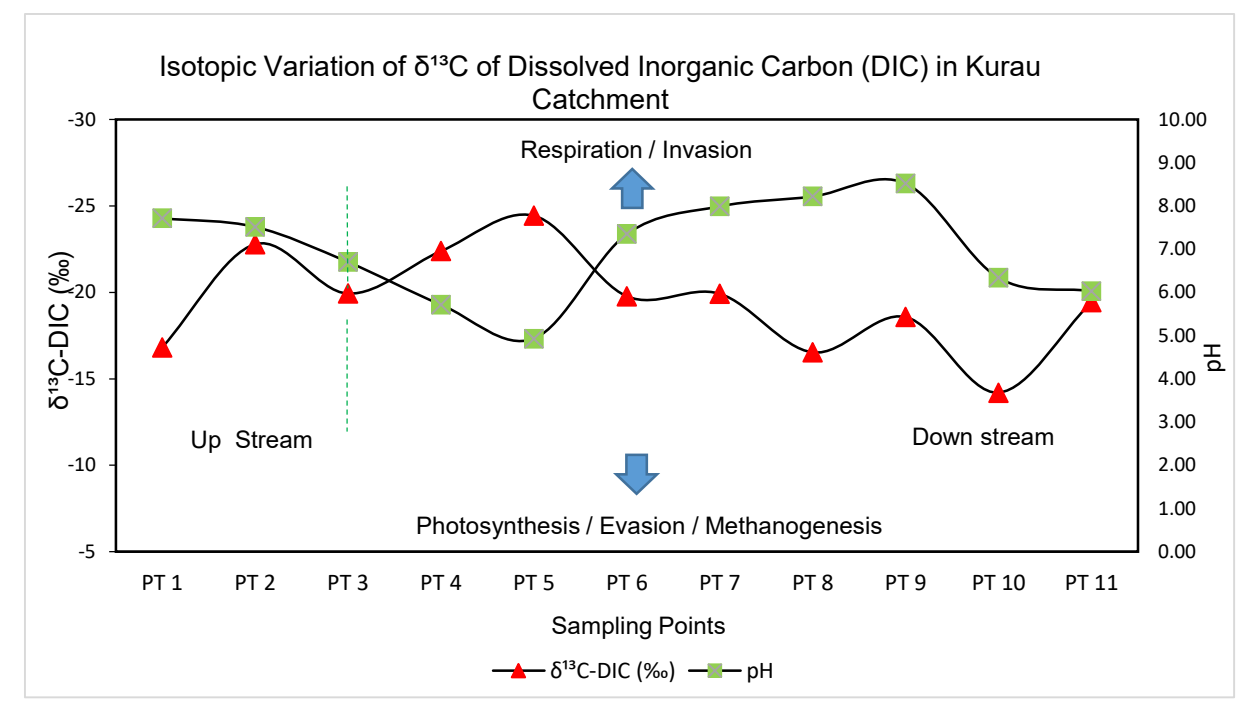

FIGURE 5. Isotopic signature of $\delta^{13} \mathrm{C}$-DIC in Kurau Catchment 
However, based on $\mathrm{pH} 7.72 \pm 0.60$, geo-genic factor need to be considered such as dissolution of carbonate material from weathering factor which tend to enhance the $\delta^{13} \mathrm{C}$ (Stephens \& Rose 2005). Hypothetically the source of DIC in PT 1 might come from the atmosphere that go through carbon fixation process and sink to the stream. Still, DIC derived from rock weathering do affect the isotopic values (Park \& Epstein 1961). As the water move downward, $\delta^{13} \mathrm{C}$-DIC show a depletion signature at PT 2 following respiration trend (Figure 5). Hypothetically, PT 2 will follow PT 1 signature since PT 2 is at the upstream river and quite close to each other. Depletion of $\delta^{13} \mathrm{C}$-DIC at PT 2 is suspected due to $\mathrm{CO}_{2}$ invasion in to the river because of less cover shade at the sampling point to promote photosynthesis process, causing more ${ }^{12} \mathrm{CO}_{2}$ dissolved in the water and additional factor such of low partial pressure, solubility of $\mathrm{CO}_{2}$ and low water temperature.

Based on the $\mathrm{pH}$ value $7.52 \pm 0.51$, the river condition is slightly alkali due to presence of carbonate mineral, but it only have minor effect since invasion process is more dominant. PT 3 (confluence - Sg Kurau \& Sg Ara) show slightly enrichment than PT 2, possibly preferential of ${ }^{12} \mathrm{CO}_{2}$ loss through evasion process and water mixing from Sungai Ara. PT $3 \mathrm{pH}$ is at $6.70 \pm 0.09$ which is slightly acidic, might be due to addition of $\mathrm{C} 3$ organic matter to the stream since free $\mathrm{CO}_{2}$ present $\mathrm{pH}$ below 7 . Due to evasion process, the escape $\mathrm{CO}_{2}$ affect the $\delta^{13} \mathrm{C}$ - DIC resulting more enriched value. Thus, the source of DIC at PT 3 might be the mineralization of DOC resulting free $\mathrm{CO}_{2}$ in the system where based on field observation the water is turbid suggesting high transported of organic matter.

High depleted signature of $\delta^{13} \mathrm{C}$ - DIC was detected at PT 5 followed by PT 4 suggesting high microbial respiration may occur in the water column. Sungai Merah and surrounding terrestrial is suspected to be the source of organic carbon which causes active respiration process at the sampling points. This was observed, when microorganism uptake of carbon substrates it can be more $-20 \%{ }^{8}$ PT 5 show the highest respiration signature with $\delta^{13} \mathrm{C}$ - DIC $-24.44 \pm 0.59 \%$ compared to PT 4 with $-22.39 \pm 0.74 \%$. The cause of high respiration is suspected from palm oil plantation near to lake side which may have contributed to the addition of particulate organic carbon (POC) that washout into the lake. These POC are consumed by microorganism thus increasing the rate of respiration in the water (Stelzer et al. 2003).

In 2010, Department of Irrigation and Drainage (DID) Kerian has reported that there is a major land clearing for replanting by privately own property. Land clearing have the highest tendency for soil to leach down into the lake cause by surface run off with siltation (mixed with POC) thus degrading water quality (Andriesse \& Schelhaas 1987). High respiration will promote more dissolved $\mathrm{CO}_{2}$ (by product) in the water hence resulting a deplete signature of $\delta^{13} \mathrm{C}$ - DIC (Striegl et al. 2001). PT 6 and PT 7 show and intermediate range between respiration, evasion or aquatic photosynthesis process. The possible explanations are this might due to overlapping process between microbial respiration and evasion or aquatic photosynthesis process causing the value shift intermediately.

PT 9 show possible source from biogenic and geogenic where the isotopic signature falls under 3 possible source which is $\mathrm{C} 3$ organic matter, soil $\mathrm{CO}_{2}$, aquatic DOC mineralization or $\mathrm{CH}_{4}$ oxidation. However, the $\mathrm{pH} 8.52 \pm 0.11$, shown sign of carbonate mineral in the water column. As mention by Stephens and Rose (2005), addition of carbonate mineral will enrich the isotopic values. In general, since the isotopic value do not enrich, it is safe to assume the source of IC is from either $\mathrm{C} 3$ organic matter, soil $\mathrm{CO}_{2}$, aquatic DOC mineralization or $\mathrm{CH}_{4}$ oxidation. PT $11 \delta^{13} \mathrm{C}$ - DIC show a depleted signature suggesting respiration process and the $\mathrm{pH}$ is $6.03 \pm 0.27$ which is in the acidic condition. The possible source at PT 11 is from explanations aquatic DOC mineralization where this point is full of dead trees (swampy condition). The water is yellowish in color suggesting high in carbonic acid.

Unique fractionation of $\delta^{13} \mathrm{C}$-DIC showed a possible of methanogenesis process at PT 10 and PT 8. High enrichment of $\delta^{13} \mathrm{C}$-DIC are detected at PT 10 which is located near Bukit Merah Resort while PT 8 it at Selinsing Water Gate. It is hypothesized that the enrichment of $\delta^{13} \mathrm{C}$ - DIC is due to production of $\mathrm{CH}_{4}$ through hydrogenotrophic methanogenesis $\left(\mathrm{CO}_{2}\right.$ reduction pathway) at PT 10 and the $\mathrm{pH}$ fall to $6.34 \pm 0.44$. Clark and Fritz (1997) explained, because of different metabolic pathway of methanogenic bacteria, it causes the carbon of $\mathrm{CH}_{4}$ to fractionate more depleted and enrich for carbon of $\mathrm{CO}_{2}$. Methanogenesis happen when inorganic oxidant such as nitrate, ferric iron or sulphate are depleted (Conrad 2005). There are 3 clues that may contribute to methanogenesis process based on our field observation and in-situ measurement (preliminary) in the lake which is: Present of micro-bubble when the sediment is tampered (suspect methane loss from the sediment through the atmosphere via ebullition); Low concentration of dissolved oxygen, 4-6 mg/L; and Low concentration of Nitrate, 1.2 $\mathrm{mg} / \mathrm{L}$. Hypothetically, the increase of $\mathrm{CO}_{2}$ concentration and decrease oxygen are early sign of anoxic pathway in sediment respiration thus supporting $\mathrm{CH}_{4}$ production (Holgerson \& Raymond 2016). Talib et al. (2016) reported the concentration of total nitrogen (TN) have a decreasing trend from upstream to downstream (Figure 6).

Total nitrogen (TN) is the sum of $\mathrm{NO}_{3}, \mathrm{NO}_{2}$, organic nitrogen, and $\mathrm{NH}_{4}$ (all expressed as $\mathrm{N}$ ). TN have derived from various source such as soil runoff, fertilizer from cropland, septic discharge, runoff from animal manure, and industrial discharge. TN reduction (\%) is inversely proportional to the distance from inlet (Sungai Kurau) in BMR. Table 2 shows a total of $61.84 \mathrm{t}$ year- 1 of inorganic 
nitrogen $\left(\mathrm{NO}_{3}, \mathrm{NO}_{2}\right.$, and $\left.\mathrm{NH}_{4}\right)$ are transported in to the lake via Sungai Kurau. High source of inorganic nitrogen suggesting the present of anthropogenic activities at the upstream of the catchment. Anthropogenic activities caused high total suspended solid (TSS) input of sedimentation to BMR. Ismail and Najib (2011) reported 51,270 t year-1 from Sungai Kurau and 2,831.9 t year1 Sungai Merah were transported into BMR. We can conclude that high TSS input bring more nutrient in BMR.

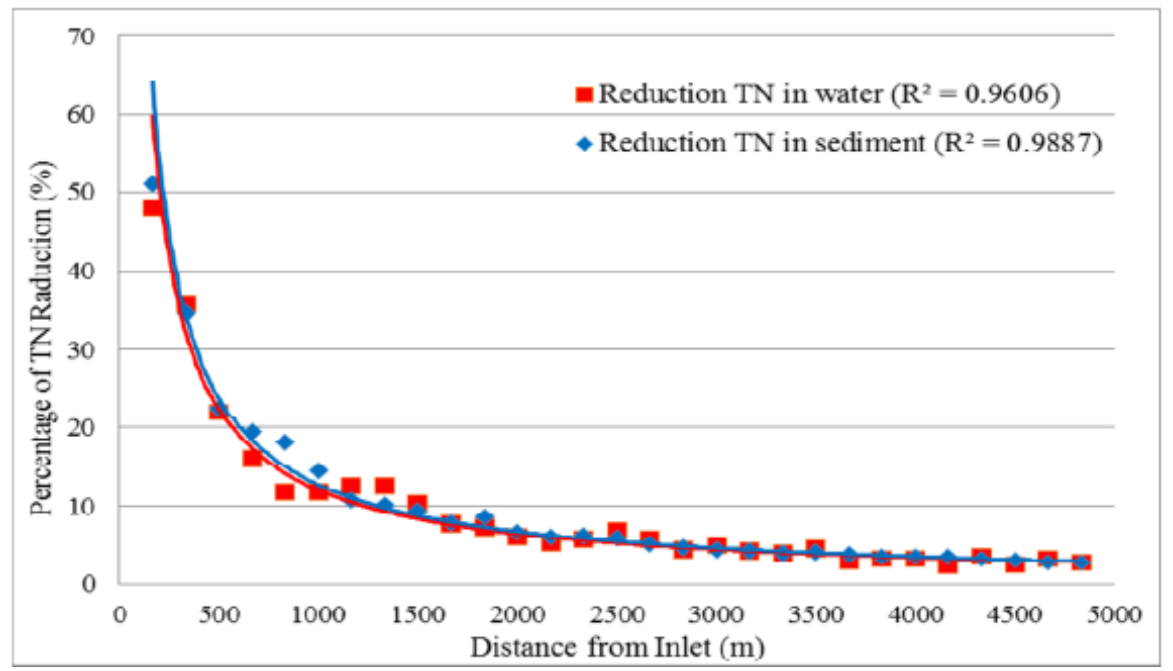

FIGURE 6. Relationship between nitrogen concentration in water and sediment with distance from inlet (Sungai Kurau). Adapted from Talib et al. (2016)

TABLE 2. Sediment and nutrient input of Bukit Merah Reservoir. Modified from Ismail and Najib (2011)

\begin{tabular}{lccccc}
\hline Nutrient input & $\mathrm{NO}_{3}$ & $\mathrm{NO}_{2}$ & $\mathrm{NH}_{4}$ & $\mathrm{PO}_{4}$ & $\mathrm{TSS}$ \\
\hline Sungai Merah & 4.17 & 0.15 & 2.16 & 5.05 & 2831.9 \\
Sungai Kurau & 39.81 & 2.92 & 19.11 & 68.32 & 51270 \\
Total input (t year-1) & 43.98 & 3.07 & 21.27 & 73.37 & 54101.9 \\
\hline
\end{tabular}

* $\mathrm{NO}_{3}$, nitrate; $\mathrm{NO}_{2}$, nitrite; $\mathrm{NH}_{4}$, ammonia; $\mathrm{PO}_{4}$, phosphate; TSS, total suspended solid

Table 2 shows that high TSS carry more nutrient input into BMR especially Sungai Kurau. Inorganic nitrogen is total of $\mathrm{TN}$, the data suggesting if the inorganic nitrogen follow the same trend of organic nitrogen in $\mathrm{TN}$ reduction over distance, this proof that low inorganic nitrogen (e.g. $\mathrm{NO}_{3}$ ) may triggered the methanogenesis process at PT 10 causing the $\delta^{13} \mathrm{C}$-DIC to be enriched. PT 8 also shown enrich value of $\delta^{13} \mathrm{C}$-DIC but the $\mathrm{pH}$ is $8.22 \pm 0.28$ which is alkali. The possible explanation might be due to the presence of mineral such as calcium carbonate $\left(\mathrm{CaCO}_{3}\right)$ or magnesium carbonate $\left(\mathrm{MgCO}_{3}\right)$ near the dam outlet. DID (2010) also reported there are high sedimentation at PT 8 shallowing the outlet of the dam. This explanation might proof the source of IC is from carbonate mineral presence there.

\section{CONCLUSION}

This is the first hydrological study using stable isotope in Perak especially Kurau catchment. The results represent 
a snapshot of carbon cycle in Kurau catchment. The stable isotopic composition of DIC was studied as a potential tracer of IC generation and pathway process in Kurau catchment. These changes are attributed to combination of complex process in the carbon pool such as depleted biogenic source of $\delta^{13} \mathrm{C}$ (microbial respiration and decay), enriched geogenic source of $\delta^{13} \mathrm{C}$ (due to photosynthesis, evasion and methanogenesis). As well, the results indicate photosynthesis activity at the upper stream system where microbial respiration process is observed to occur at the Bukit Merah lake located at downstream area. The dynamic of carbon pathway is highly affected by allochthonous input and autochthonous process in the catchment system. Land use activities within the catchment can disturb the balance between biological and geological processes which control the carbon pool in Kurau catchment.

\section{ACKNOWLEDGEMENTS}

We would like to thank Universiti Sains Malaysia (USM) for the financial support through the research grant No. 304.PTEKIND.6316496.

\section{REFERENCES}

Andriesse, J.P. \& Schelhaas, R.M. 1987. A monitoring study on nutrient cycles in soils used for shifting cultivation under various climatic conditions in tropical Asia. III. The effects of land clearing through burning on fertility level. Agriculture, Ecosystems \& Environment 19(4): 311-332.

Berner, E.K. \& Berner, R.A. 2012. Global Environment: Water, Air, and Geochemical Cycles. New Jersey: Princeton University Press.

Cerling, T.E., Solomon, D.K., Quade, J. \& Bowman, J.R. 1991. On the isotopic composition of carbon in soil carbon dioxide. Geochimica et Cosmochimica Acta 55(11): 34033405.

Clark, I.D. \& Fritz, P. 2013. Environmental Isotopes in Hydrogeology. Boca Raton: CRC Press.

Conrad, R. 2005. Quantification of methanogenic pathways using stable carbon isotopic signatures: A review and a proposal. Organic Geochemistry 36(5): 739-752.

DID. 2010. Bukit Merah Lake Brief. NRE Putrajaya: Department of Irrigation and Drainage, Kerian.

Dubois, K.D., Lee, D. \& Veizer, J. 2010. Isotopic constraints on alkalinity, dissolved organic carbon, and atmospheric carbon dioxide fluxes in the Mississippi River. Journal of Geophysical Research: Biogeosciences 115(G2): 1-8.

Farquhar, G.D., Ehleringer, J.R. \& Hubick, K.T. 1989. Carbon isotope discrimination and photosynthesis. Annual Review of Plant Biology 40(1): 503-537.

Holgerson, M.A. \& Raymond, P.A. 2016. Large contribution to inland water $\mathrm{CO}_{2}$ and $\mathrm{CH}_{4}$ emissions from very small ponds. Nature Geoscience 9(3): 222-226.

Hope, D., Billett, M.F. \& Cresser, M.S. 1994. A review of the export of carbon in river water: Fluxes and processes. Environmental Pollution 84(3): 301-324.

IAEA. 1993. Reference and intercomparison materials for stable isotope of light element. In Proceeding of a Consultants Meeting held in Vienna. Vienna, p. 165.
Ismail, W.R. \& Najib, S.A.M. 2011. Sediment and nutrient balance of Bukit Merah Reservoir, Perak (Malaysia). Lakes \& Reservoirs: Science, Policy and Management for Sustainable Use 16(3): 179-184.

Ishak, M.I.S. 2014. A reconnaissance study of water and carbon fluxes in Tropical watersheds of Peninsular Malaysia: Stable isotope constraints. $\mathrm{PhD}$ thesis, University of Ottawa (Unpublished).

Karim, A., Dubois, K. \& Veizer, J. 2011. Carbon and oxygen dynamics in the Laurentian Great Lakes: Implications for the $\mathrm{CO}_{2}$ flux from terrestrial aquatic systems to the atmosphere. Chemical Geology 281(1-2): 133-141.

Kalff, J. 2002. Limnology: Inland Water Ecosystems. Upper Saddle River, NJ: Prentice Hall.

Lee, K.Y. 2014. Carbon cycling in tropical rivers: A carbon isotope reconnaissance study of the Langat and Kelantan basins. $\mathrm{PhD}$ thesis, University of Ottawa (Unpublished).

Mackenzie, F.T. \& Lerman, A. 2006. Carbon in the Geobiosphere: Earth's Outer Shell. Netherlands: Springer Science \& Business Media.

Meybeck, M. 1993. Riverine transport of atmospheric carbon: Sources, global typology and budget. Water, Air, and Soil Pollution 70(1-4): 443-463.

Park, R. \& Epstein, S. 1961. Metabolic fractionation of $C^{13} \& C^{12}$ in plants. Plant Physiology 36(2): 133-138.

SERCON. 2007. Isotope Ratio Mass Spectrometer (IRMS) Operation Manual. U.K: SERCON Group.

Stelzer, R.S., Heffernan, J. \& Likens, G.E. 2003. The influence of dissolved nutrients and particulate organic matter quality on microbial respiration and biomass in a forest stream. Freshwater Biology 48(11): 1925-1937.

Stephens, M. \& Rose, J. 2005. Modern stable isotopic ( $\delta 18 \mathrm{O}$, $\delta 2 \mathrm{H}, \delta 13 \mathrm{C})$ variation in terrestrial, fluvial, estuarine and marine waters from north-central Sarawak, Malaysian Borneo. Earth Surface Processes and Landforms 30(7): 901-912.

Striegl, R.G., Kortelainen, P., Chanton, J.P., Wickland, K.P., Bugna, G.C. \& Rantakari, M. 2001. Carbon dioxide partial pressure and ${ }^{13} \mathrm{C}$ content of north temperate and boreal lakes at spring ice melt. Limnology and Oceanography 46(4): 941-945.

Talib, S.H.A., Yusoff, M.S., Hasan, Z.A., Ismail, W.R. \& Abustan, M.S. 2016. Nutrient concentration distribution in sediment and overlying water at Bukit Merah reservoir, Perak. In

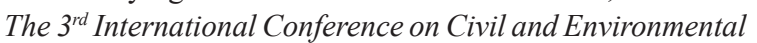
Engineering for Sustainability (IConCEES 2015). pp. 1-8.

Varlam, C., Stefanescu, I., Varlam, M., Bucur, C., Popescu, I. \& Faurescu, I. 2006. Optimization of ${ }^{14} \mathrm{C}$ concentration measurement in aqueous samples using the direct absorption method and LSC. Advances in Liquid Scintillation Spectrometry 49: 423-428.

Wanninkhof, R. 1985. Kinetic fractionation of the carbon isotopes ${ }^{13} \mathrm{C}$ and ${ }^{12} \mathrm{C}$ during transfer of $\mathrm{CO}_{2}$ from air to seawater. Tellus B: Chemical and Physical Meteorology 37(3): 128-135.

Weiss, R.F. 1974. Carbon dioxide in water and seawater: The solubility of a non-ideal gas. Marine Chemistry 2(3): 203-215.

Whiticar, M.J., Faber, E. \& Schoell, M. 1986. Biogenic methane formation in marine and freshwater environments: $\mathrm{CO}_{2}$ reduction vs. acetate fermentation - isotope evidence. Geochimica et Cosmochimica Acta 50(5): 693-709. 
Williamson, C.E., Saros, J.E., Vincent, W.F. \& Smol, J.P. 2009. Lakes and reservoirs as sentinels, integrators, and regulators of climate change. Limnology and Oceanography 54(6part2): 2273-2282.

Zou, J. 2016. Correction: Sources and dynamics of inorganic carbon within the upper reaches of the Xi River basin, Southwest China. PloS ONE 11(12): e0169379.

Mohamad Shaiful Md Yusuff, Muhammad Izzuddin Syakir* \& Widad Fadhullah

Environmental Technology Division

School of Industrial Technology

Universiti Sains Malaysia

11800 Minden, USM Pulau Pinang

Malaysia
Muhammad Izzuddin Syakir*

Centre for Global Sustainability Studies

Universiti Sains Malaysia

11800 Minden, USM Pulau Pinang

Malaysia

*Corresponding author; email: misyakir@usm.my

Received: 17 March 2019

Accepted: 25 March 2020 